\title{
THE MAKING OF
}

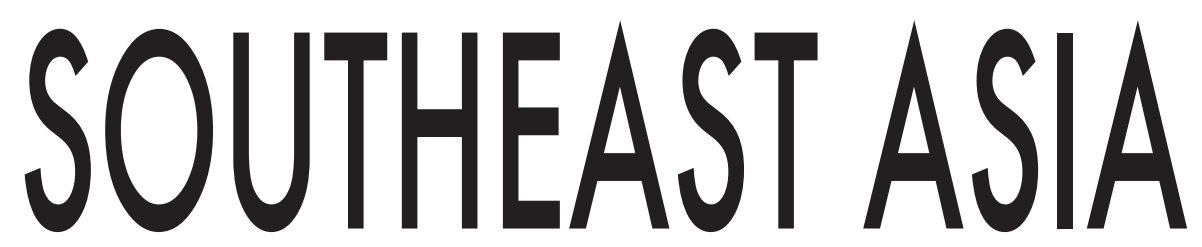

INTERNATIONAL RELATIONS OF A REGION

\section{AMITAV ACHARYA}

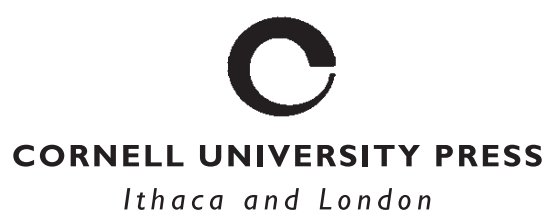

\section{누바노}


Copyright () 2012 Institute of Southeast Asian Studies, Singapore

First edition published in Singapore in 2000 by

Oxford University Press

New expanded edition published in Singapore in 2012 by

ISEAS Publishing

Institute of Southeast Asian Studies

30 Heng Mui Keng Terrace

Pasir Panjang

Singapore 119614

This reprint edition is a complete reproduction of the Singapore edition, specially authorized by the original publisher, Institute of Southeast Asian Studies, for publication and sale only in the North American and European markets.

All rights reserved. Except for brief quotations in a review, this book, or parts thereof, must not be reproduced in any form without permission in writing from the publisher. For information, address Cornell University Press, Sage House, 512 East State Street, Ithaca, New York 14850.

First printing, Cornell Paperbacks, 2013

ISBN 978-0-8014-7736-2 (paper : alk. paper)

Typeset by International Typesetters Pte Ltd Printed in the United States of America

Librarians: A CIP catalog record for this book is available from the Library of Congress.

Cornell University Press strives to use environmentally responsible suppliers and materials to the fullest extent possible in the publishing of its books. Such materials include vegetable-based, low-VOC inks and acid-free papers that are recycled, totally chlorine-free, or partly composed of nonwood fibers. For further information visit our website at www.cornellpress.cornell.edu.

$\begin{array}{lllllllllll}\text { Paperback printing } & 10 & 9 & 8 & 7 & 6 & 5 & 4 & 3 & 2 & 1\end{array}$

Cover photos: The images of the tall buildings and the battleship are from Shutterstock; the map of Southeast Asia is by Getty Images. 
"This book is a landmark in the process it describes. Southeast Asia's 'quest for identity'; its imagining of a common destiny, has found a worthy chronicler and analyst in Amitav Acharya."

Anthony Reid

Emeritus Professor,

Australian National University

"extremely insightful, timely, and instructive"

Harvard Asia Quarterly

“... this is a thought-provoking book, loaded with valuable observations and insights. It also provides a needed corrective to orientalist perspective and to the sometimes tunnel vision of international relations scholars. It is highly recommended, and should be added to the reading lists of every Southeast Asia international relations course."

Contemporary Southeast Asia

"The book succeeds on a number of levels. For one thing, it pays close attention to the notion of 'region' rather than simply examining the various individual parts that constitute the area we now regard as Southeast Asia. In doing so it stakes out new ground not only in theoretical terms but practical ones as well. Moreover, because the development of a regional identity has been consumed with efforts to create a unity amongst its members, the charting of its successes, its failures, its hopes and prospects is a worthwhile task in itself. The author is not simply content to lay out the history of these in analytical fashion but rather seeks to go beyond in assessing the way in which regionalism has affected how they see themselves in terms of regional identity."

International Affairs

“... an excellent and compelling historical overview of regional relations and regionalism in Southeast Asia. One of Acharya's stated objectives in writing the book is to address a lack of historical analysis among political scientists when it comes to examining Southeast Asia ... This is an important book, which makes a valuable contribution towards the study of Southeast Asian regionalism by opening new areas for discussion and debate about this concept." 
"In his comparative approach, ... [Acharya] challenges the 'gap' between discipline-based approach and the country-specific approach adopted by many area specialists ... While dealing with great complexity, Acharya is able to present his ideas clearly and concisely ..."

Journal of Contemporary Asia

"The book ... is timely in its attempt to discern the conceptual meaning of Southeast Asia's efforts to forge its own identity ... The Quest for Identity will be a welcome source for newcomers to the field. With its easy-to-read and subtle presentation of major topics, readers should be tempted into a deeper exploration of the field of Southeast Asian international relations."

International Relations of the Asia-Pacific

“... numerous insights and important but neglected facts to be learned from this account ..."

Australian Journal of International Affairs

“a perceptive study ... Southeast Asia is different from Europe, South Asia or the Middle East ... If ... ASEAN's core countries managed heroically to imagine themselves in Benedict Anderson's sense to be an entity, it was mainly because of the Cold War and the conflict in Vietnam. In the process, they developed cohesion, confidence and a sense of purpose. Acharya also exposes the hype ..."

Times Higher Education Supplement 


\section{THE MAKING OF SOUTHEAST ASIA}


A volume in the series

Cornell Studies in Political Economy

edited by Peter J. Katzenstein

A list of titles in this series is available at www.cornellpress.cornell.edu.

The Institute of Southeast Asian Studies (ISEAS) was established as an autonomous organization in 1968. It is a regional research centre dedicated to the study of socio-political, security and economic trends and developments in Southeast Asia and its wider geostrategic and economic environment. The Institute's research programmes are the Regional Economic Studies (RES, including ASEAN and APEC), Regional Strategic and Political Studies (RSPS), and Regional Social and Cultural Studies (RSCS).

ISEAS Publishing, an established academic press, has issued more than 2,000 books and journals. It is the largest scholarly publisher of research about Southeast Asia from within the region. ISEAS Publishing works with many other academic and trade publishers and distributors to disseminate important research and analyses from and about Southeast Asia to the rest of the world. 


\section{Dedication}

The late Ananda Rajah, a social anthropologist and close personal friend, was a steadfast enthusiast behind my attempts to imagine and interpret Southeast Asia and live the region for a dozen years. It is to his beloved memory that this book is dedicated. 
